\title{
PENGAWETAN KAYU KARET MENGGUNAKAN BAHAN ORGANIK DENGAN TEKNIK PERENDAMAN PANAS
}

\author{
Preserving of Rubber Wood by Using Organic Materials with Hot Soaking Technique \\ Afrizal VACHLEPI, Didin SUWARDIN, dan Sherly HANIFARIANTY \\ ${ }^{1}$ Balai Penelitian Sembawa - Pusat Penelitian Karet \\ J1. Raya Palembang-P.Balai Km.29 Kotak Pos 1127 Palembang \\ Sumatera Selatan 30001 \\ Email : A_Vachlepi@yahoo.com
}

Diterima : 12 Maret 2015 / Direvisi : 28 April 2015 / Disetujui : 7 Mei 2015

\begin{abstract}
Wood demand is constantly increasing. Meanwhile, the availability of forest wood is decreasing and limited. Rubber wood can be an alternative to substitute the natural wood. To improve the durability of rubber wood from destroying organisms such as insects and fungus, the prevention and preservation needed to be done. The use of chemical preservatives has negative impact on the environment. Therefore, it needs alternative organic preservatives that are more environmentally friendly. The application of preservative on rubber wood can use hot soaking technique. The treatment consists of preservative types and soaking time. Preservative materials used were liquid smoke 5\%, turmeric extract 5\%, formaldehyde 5\% and borax 5\%. While soaking time consists of $O$ (control), 1, 3, and 5 hours. Parameters observed namely retention of preservatives, weight loss, color and degree of protection. The results showed that the use of liquid smoke as a preservative rubber wood better than the turmeric extract. Retention and degree of protection of liquid smoke as a preservative was no different than chemical preservatives, borax and formaldehyde. The use of liquid smoke would only affect the color becomes light brown rubber wood after soaking. This color would change during the storage process becomes very pale brown. The best application of preservative liquid smoke was soaking for 1 hour.
\end{abstract}

Keywords: Organic materials, rubber wood, preservative

\footnotetext{
Abstrak

Kebutuhan kayu terus mengalami peningkatan. Sementara itu, ketersediaan kayu hutan semakin berkurang dan terbatas. Kayu karet dapat menjadi salah satu alternatif pengganti kayu alam. Untuk meningkatkan ketahanan kayu karet dari organisme perusak kayu seperti serangga dan jamur, perlu dilakukan pencegahan dan pengawetan. Penggunaan pengawet kimia diduga mempunyai dampak
}

negatif terhadap lingkungan. Oleh karena itu perlu alternatif pengawet organik yang lebih ramah lingkungan. Aplikasi bahan pengawet pada kayu karet alam dapat menggunakan teknik perendaman panas. Faktor perlakuan terdiri atas jenis bahan pengawet dan lama perendaman. Bahan pengawet yang digunakan berupa asap cair 5\%, ekstrak kunyit 5\%, formalin 5\% dan boraks $5 \%$. Sedangkan waktu perendaman kayu karet terdiri dari 0 (kontrol), 1, 3, dan 5 jam. Parameter yang diamati yaitu retensi bahan pengawet, penyusutan berat, warna dan derajat proteksi terhadap kerusakan. Hasil penelitian menunjukkan bahwa penggunaan asap cair sebagai bahan pengawet kayu karet lebih baik dibandingkan ekstrak kunyit. Retensi dan derajat proteksi asap cair sebagai bahan pengawet tidak berbeda dibandingkan dengan bahan pengawet kimia, boraks dan formalin. Penggunaan asap cair hanya akan mempengaruhi warna kayu karet menjadi cokelat muda setelah perendaman. Warna ini akan berubah selama proses penyimpanan menjadi cokelat sangat pucat. Aplikasi terbaik bahan pengawet asap cair adalah perendaman selama 1 jam.

Kata kunci : Bahan organik, kayu karet, pengawet

\section{PENDAHULUAN}

Permintaan kayu di pasar internasional diperkirakan terus meningkat sejalan dengan pertumbuhan penduduk dunia yang semakin pesat dan peningkatan penggunaan peralatan yang berbahan baku kayu. Sementara itu, ketersediaan kayu hutan yang selama ini menjadi sumber utama pasokan bagi industri pengolahan kayu, semakin berkurang dan terbatas (Agustina, 2012). Untuk mengatasi kondisi ini dapat dilakukan dengan mencari alternatif sumber lain pengganti kayu hutan. Salah satunya adalah kayu dari tanaman karet alam (Hevea brasiliensis). 
Boerhendhy dan Agustina (2006) menyatakan bahwa ada beberapa alasan mengapa kayu karet dapat digunakan sebagai substitusi kayu hutan alam dan menjadi andalan dalam memenuhi kebutuhan kayu baik untuk pasar dalam negeri maupun luar negeri. Alasan tersebut adalah sifat-sifat dasar kayu karet baik sifat fisik maupun mekanis sama dengan kayu hutan, potensi ketersediaan kayu karet cukup besar sejalan dengan peremajaan perkebunan karet rakyat dan nilai ekonomis kayu karet cukup baik.

Oleh karena itu beberapa negara penghasil karet alam dunia sudah mengoptimalkan pemanfaatan kayu karet untuk berbagai peralatan terutama furniture. Sebagai salah satu negara produsen karet alam terbesar di dunia dengan luas areal perkebunan karet mencapai 3,45 juta Ha pada tahun 2011 (Direktorat Jenderal Perkebunan, 2011), di Indonesia memiliki kayu karet yang sangat berpotensi menjadi salah satu alternatif pengganti kayu hutan. Berdasarkan hasil kajian Woelan et al (2012), kayu karet dapat digunakan sebagai bahan baku industri yang mempunyai nilai ekonomis yang cukup signifikan. Dari sifat mekanis, fisik, warna dan teksturnya, kayu karet termasuk dalam kelompok kayu kelas kuat II. Sayangnya keawetan kayu karet kurang baik yang termasuk dalam kelas awet $\mathrm{V}$ dimana umur pakainya pendek dan mudah hancur (Barly dan Krisdianto, 2012). Agar kayu karet awet dan terhindar dari organisme perusak kayu seperti serangga dan jamur, perlu dilakukan pencegahan yaitu dengan cara pengawetan. Penggunaan bahan kimia pengawet kayu diakui sebagai cara yang paling efektif dalam meningkatkan mutu kayu dan produknya (Barli dan Subarudi, 2010). Beberapa senyawa kimia yang paling umum digunakan sebagai pengawet kayu karet antara lain soda abu, asam boraks (Barly et al., 2011), Tembaga sulfat (Suheryanto, 2010), dan formalin.

Penggunaan senyawa kimia sintetik ini diduga dapat mengganggu kesehatan manusia terutama penggunaan dengan waktu yang lama dan mencemari lingkungan yang berasal dari limbah cair yang dihasilkan. Dengan semakin pedulinya manusia terhadap kesehatan dan lingkungan, penggunaan bahan kimia dalam berbagai industri termasuk industri pengolahan kayu karet terus dikurangi dan bahkan ada kecenderungan untuk menggantinya dengan pengawet yang lebih ramah lingkungan. Alternatif bahan pengawet yang ramah lingkungan umumnya berasal dari alam berupa bahan organik. Beberapa bahan organik yang sudah diteliti sebagai bahan pengawet alami antara lain asap cair (Purwani dan Muwakhidah, 2008) dan kunyit (Hartati, 2013). Dari hasil penelitian tersebut sudah membuktikan bahwa asap cair dan kunyit mampu digunakan sebagai bahan pengawet.

Tujuan penelitian ini adalah untuk mengetahui dan mempelajari kemampuan asap cair dan ekstrak kunyit sebagai bahan pengawet organik untuk kayu karet alam. Hasil penelitian ini diharapkan dapat menjadi indikator awal untuk menggantikan penggunaan bahan kimia sintetik sebagai bahan pengawet kayu karet.

\section{BAHAN DAN METODE}

Penelitian ini dilakukan di Laboratorium Teknologi Pengolahan, Balai Penelitian Sembawa dari bulan November 2012 sampai Juli 2013. Bahan yang digunakan terdiri atas kayu karet yang berasal dari kebun percobaan Balai Penelitian Sembawa, asap cair murni, ekstrak kunyit, formalin dan boraks. Alat yang digunakan berupa timbangan, jangka sorong, Munselt color chart, water bath, dan pengaduk magnetik.

Aplikasi bahan pengawet pada kayu karet alam dilakukan dengan menggunakan teknik perendaman panas. Faktor perlakuan yang diberikan terdiri atas jenis bahan pengawet dan waktu perendaman. Jenis bahan pengawet yang digunakan berupa asap cair $5 \%$, ekstrak kunyit $5 \%$, formalin $5 \%$ dan boraks 5\%. Sedangkan waktu perendaman kayu karet terdiri dari 0 (kontrol), 1, 3, dan 5 jam. Parameter yang diamati yaitu retensi bahan pengawet, penyusutan berat, warna, dan derajat proteksi terhadap kerusakan.

Tahap awal penelitian ini berupa persiapan kayu karet dengan cara memotong kayu karet dengan ukuran yang sama, yaitu tinggi sekitar $10 \mathrm{~cm}$. Kayu karet yang digunakan berasal dari cabang pohon karet yang diambil dari kebun riset Balai 
Penelitian Sembawa. Kayu karet yang digunakan sebagai sampel penelitian disajikan pada Gambar 1. Setiap sampel kayu yang digunakan ditimbang dan diukur dimensinya menggunakan jangka sorong berupa diameter dan tinggi.

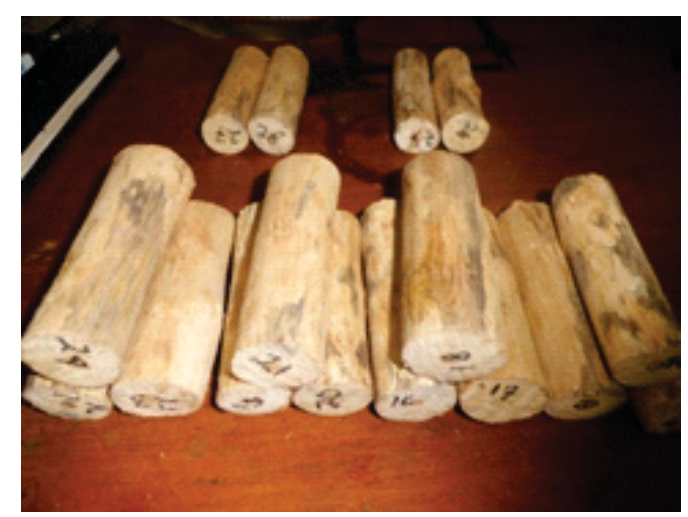

Gambar 1. Sampel kayu karet yang diawetkan menggunakan berbagai bahan pengawet Figure 1. Rubber wood samples were preserved by using various preservatives

Sebelum diaplikasikan, bahan pengawet (asap cair, ekstrak kunyit, boraks dan formalin) dilarutkan terlebih dahulu menjadi larutan berkonsentrasi 5\% menggunakan aquadest. Selanjutnya sampel kayu direndam ke dalam masingmasing larutan bahan pengawet. Lama perendaman dilakukan sesuai dengan perlakuan yaitu 1, 3 dan 5 jam dengan suhu $60^{\circ} \mathrm{C}$ menggunakan water bath. Setelah perendaman, setiap sampel karet diangkat dari dalam bahan pengawet untuk dikeringanginkan sekitar 30 menit.

\section{Prosedur pengujian}

a. Retensi bahan Pengawet

Retensi merupakan jumlah bahan pengawet tanpa larutan yang telah masuk ke dalam kayu karet (Suheryanto, 2010). Retensi dapat dihitung dengan persamaan berikut :

Retensi $\left(\frac{\mathrm{kg}}{\mathrm{m}^{3}}\right)=\frac{W_{i}-W_{o}}{\mathrm{~V}} \times C$

dimana :

$\mathrm{W}_{\mathrm{i}}=$ berat sampel kayu karet setelah diawetkan (kg)

$\mathrm{W}_{\mathrm{o}}=$ berat sampel kayu karet sebelum diawetkan (kg)

$\mathrm{V}=$ volume sampel kayu karet $\left(\mathrm{m}^{3}\right)$

$\mathrm{C}=$ konsentrasi larutan bahan pengawet (\%) b. Penyusutan berat kayu karet selama penyimpanan

Penyusutan berat selama penyimpanan dianalisis untuk mengetahui perubahan berat kaitannya dengan kandungan air dalam kayu. Parameter ini diamati dengan cara menimbang berat kayu karet setiap 1 minggu. Penimbangan awal dilakukan setelah kayu karet direndam dan dikering-anginkan sesuai dengan perlakuan.

\section{c. Warna}

Aplikasi bahan pengawet organik dapat mempengaruhi warna kayu karet. Pengujian warna diperlukan untuk mengetahui perubahan warna kayu karet selama penyimpanan. Pengujian warna kayu karet dilakukan secara visual dengan membandingkan warna kayu karet dengan standar warna yang tercantum dalam Munselt color chart. Pengamatan dilakukan setiap 1 bulan sekali selama 6 bulan dan diawali setelah proses perendaman.

d. Derajat proteksi terhadap kerusakan

Derajat proteksi terhadap kerusakan sampel kayu diukur berdasarkan pengamatan visual. Sampel kayu yang sudah diaplikasikan bahan pengawet dibiarkan di ruang terbuka selama 6 bulan dan diamati setiap 1 bulan sekali. Derajat proteksi sampel kayu karet ditentukan melalui pemberian nilai (scoring) dalam skala yang ditampilkan pada Tabel 1 . 
Tabel 1. Skala derajat proteksi terhadap kerusakan Table 1. Degree scale of protection against damage

\begin{tabular}{cl}
\hline $\begin{array}{c}\text { Nilai } \\
\text { Score }\end{array}$ & \multicolumn{1}{c}{\begin{tabular}{c}
\multicolumn{1}{c}{ Keadaan serangan } \\
Attack condition
\end{tabular}} \\
\hline 100 & $\begin{array}{l}\text { baik (tidak ada serangan) } \\
\text { Good (no attack) } \\
\text { Sedikit (nyata di permukaan) } \\
\text { Little (real on the surface) } \\
\text { Banyak (nyata di permukaan) } \\
\text { Many (real on the surface) } \\
\text { Sedang (masuk tetapi belum meluas) } \\
\text { Medium (penetrated but not yet } \\
\text { widespread) } \\
\text { Hebat (masuk sudah meluas) } \\
\text { bad (penetrated and already widespread } \\
\text { Hebat (hancur) } \\
\text { Very bad (crush) }\end{array}$ \\
\hline
\end{tabular}

\section{HASIL DAN PEMBAHASAN}

\section{Retensi bahan pengawet}

Retensi berbagai bahan pengawet sesuai dengan lama perendaman ditampilkan pada Gambar 2. Nilai retensi berbagai bahan pengawet semakin meningkat dengan semakin lamanya waktu perendaman (Gambar 2). Nilai retensi paling tinggi dihasilkan kayu karet yang direndam dengan larutan asap cair 5\% selama 5 jam, yaitu $20,81 \mathrm{~kg} / \mathrm{m}^{3}$ dengan persentase peningkatan berat sampel kayu yang mencapai $78 \%$ dari berat awal. Kayu karet yang direndam di dalam larutan boraks $5 \%$ selama 1 jam mempunyai nilai retensi paling kecil yaitu $3,41 \mathrm{~kg} / \mathrm{m}^{3}$ dan persentase peningkatan berat sampel hanya sekitar $15 \%$ dari berat awal. Suheryanto (2010) menyatakan bahwa retensi bahan pengawet merupakan indikator keberhasilan proses pengawetan. Bahan pangawet yang mempunyai kemampuan retensi yang tinggi mengindikasikan bahwa bahan pengawet tersebut mampu terserap (terabsorpsi) dengan baik ke dalam kayu karet. Jumlah bahan pengawet yang terserap ke dalam kayu karet akan menentukan tingkat keefektifannya dalam melindungi kayu karet dari gangguan organisme perusak.

\section{Penyusutan berat kayu karet selama penyimpanan}

Secara umum, berat kayu karet akan mengalami penyusutan selama penyimpanan (Gambar 3). Penyusutan berat paling besar terjadi pada minggu ke-1 setelah proses perendaman. Hal ini

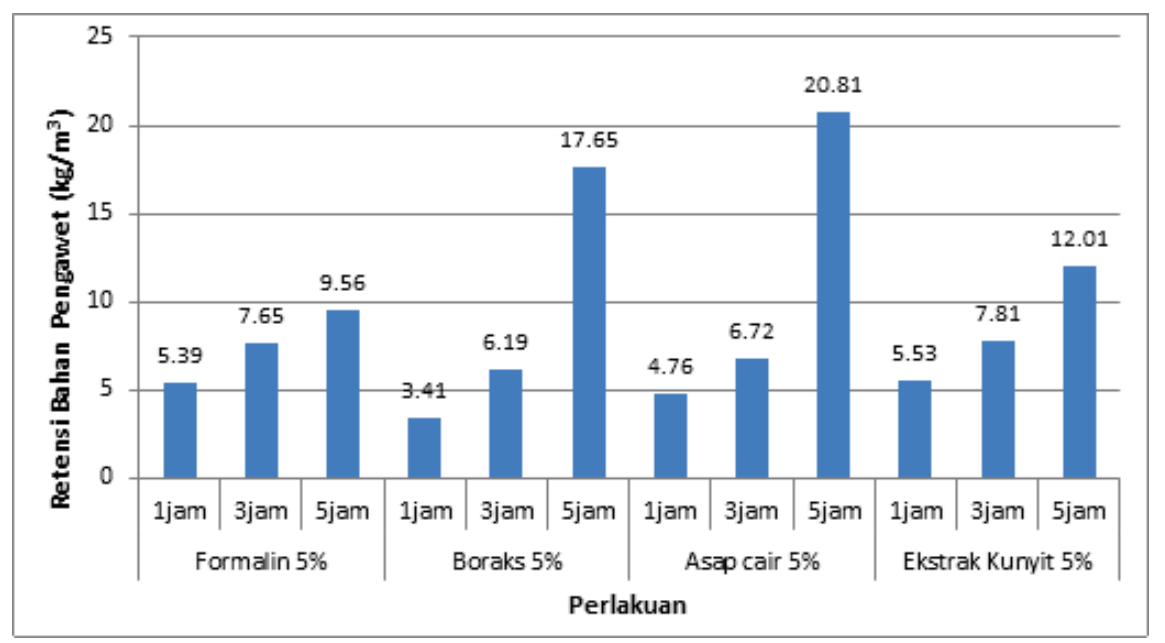

Gambar 2. Retensi bahan pengawet pada berbagai waktu perendaman Figure 2. Preservatives retention at various soaking time 


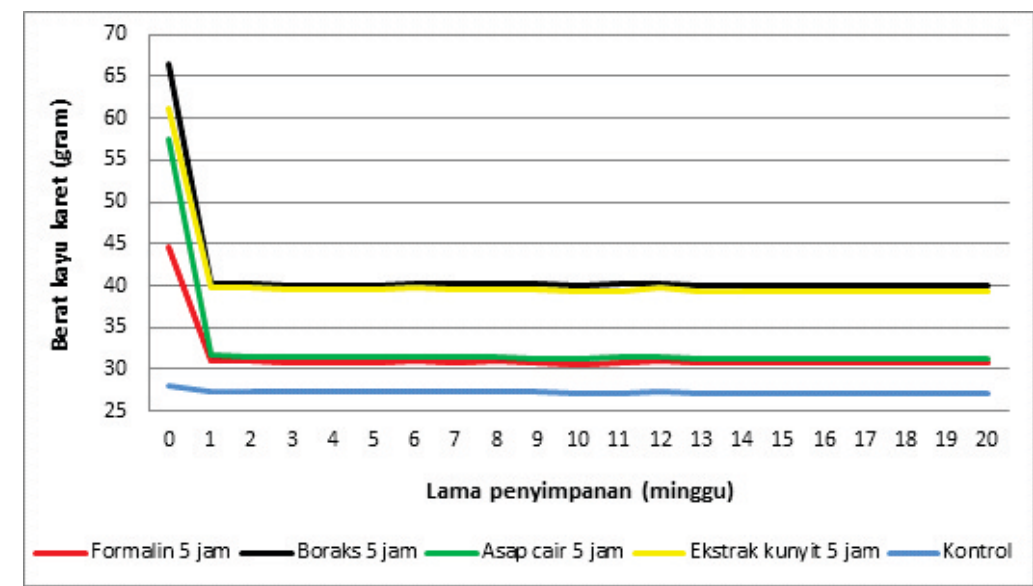

Gambar 3. Penyusutan berat kayu karet selama penyimpanan

Figure 3. Weight shrinkage of rubber wood during storage

disebabkan air dari bahan pengawet yang terserap (terabsorpsi) selama proses perendaman akan menguap sangat banyak. Jumlah penyusutan berat yang paling kecil terjadi pada kayu karet kontrol yaitu sebesar 1 gram atau sekitar $3 \%$ dari berat awal. Hal ini dikarenakan pada kayu kontrol tidak dilakukan perendaman yang artinya tidak ada air yang terserap ke dalam kayu. Sedangkan kayu karet yang direndam dengan asap cair 5\% selama 5 jam mengalami penyusutan paling besar yaitu 25,7 gram atau sekitar 45\% dari berat setelah perendaman. Hal ini terjadi karena asap cair bersifat "syneresis effect" yaitu mampu mengeluarkan air dari bahan.

Berdasarkan Gambar 3 dapat dilihat bahwa setelah penyimpanan lebih dari 1 minggu, penyusutan berat pada semua perlakuan kayu karet relatif sangat kecil. Hasil ini memberikan gambaran bahwa berat kayu karet yang direndam menggunakan teknik perendaman panas sudah relatif konstan setelah disimpan selama 1 minggu.

\section{Warna}

Hasil analisis warna kayu karet yang sudah diberi perlakuan perendaman dengan berbagai bahan pengawet ditampilkan pada Tabel 2. Dari hasil analisis diketahui bahwa kayu karet alam (kontrol) mempunyai warna kuning oranye pucat (pale orange yellow) yang akan berubah menjadi warna cokelat sangat pucat (very pale brown) selama proses penyimpanan. Aplikasi bahan pengawet organik berupa ekstrak kunyit dan asap cair dengan konsentrasi 5\% sangat mempengaruhi warna asli kayu karet alam. Aplikasi ekstrak kunyit 5\% membuat kayu karet berwarna kuning terutama yang direndam selama 5 jam. Pada perlakuan yang direndam ekstrak kunyit 5\% selama 1 jam, warna kayu akan mengalami perubahan dari kuning menjadi cokelat pucat setelah disimpan lebih dari 3 bulan.

Kayu karet yang direndam dengan asap cair 5\% akan berwarna cokelat muda. Warna kayu ini akan mengalami perubahan setelah disimpan. Untuk kayu karet yang direndam selama 1 jam, perubahan warna dari cokelat muda menjadi cokelat sangat pucat terjadi pada bulan ke-1. Kayu karet yang direndam 3-5 jam baru akan berubah menjadi warna cokelat pucat pada bulan ke2. Warna cokelat pada kayu karet ini disebabkan kandungan fenol dan senyawasenyawa yang mengandung gugus karbonil di dalam asap cair (Solichin et al., 2007). Asap cair merupakan cairan berwarna cokelat yang dihasilkan dari pirolisis cangkang kelapa sawit (Vachlepi dan Solichin, 2008).

Penggunaan bahan pengawet kimia boraks dan formalin 5\% tidak terlalu mempengaruhi warna kayu karet. Warna kayu karet yang direndam dengan formalin 5\% sama dengan warna kayu karet kontrol. Sedangkan kayu karet yang direndam dengan boraks 5\% mempunyai warna cokelat pucat (pale brown) setelah perendaman. Warna ini akan memudar 
Tabel 2. Warna kayu karet yang diawetkan dengan berbagai bahan pengawet selama penyimpanan

Table 2. Color of rubber wood preserved with various preservatives during storage

\begin{tabular}{|c|c|c|c|c|}
\hline \multicolumn{2}{|c|}{$\begin{array}{l}\text { Perlakuan } \\
\text { Treatments }\end{array}$} & \multicolumn{3}{|c|}{$\begin{array}{l}\text { Warna kayu karet (per bulan) } \\
\text { Rubber wood color (per months) }\end{array}$} \\
\hline $\begin{array}{c}\text { Jenis bahan } \\
\text { pengawet } \\
\text { Preservative type }\end{array}$ & $\begin{array}{c}\text { Lama } \\
\text { perendaman } \\
\text { Soaking time }\end{array}$ & 0 & 3 & 6 \\
\hline \multirow{2}{*}{$\begin{array}{c}\text { Ekstrak kunyit } \\
5 \% \\
\text { Turmeric extract 5\% }\end{array}$} & $\begin{array}{l}1 \text { jam } \\
1 \text { hour }\end{array}$ & $\begin{array}{l}\text { kuning } \\
\text { yellow }\end{array}$ & $\begin{array}{r}\text { kuning } \\
\text { yellow }\end{array}$ & $\begin{array}{l}\text { cokelat pucat } \\
\text { pale brown }\end{array}$ \\
\hline & $\begin{array}{c}5 \text { jam } \\
5 \text { hours }\end{array}$ & $\begin{array}{l}\text { kuning } \\
\text { yellow }\end{array}$ & $\begin{array}{l}\text { kuning } \\
\text { yellow }\end{array}$ & $\begin{array}{l}\text { kuning } \\
\text { yellow }\end{array}$ \\
\hline \multirow{2}{*}{$\begin{array}{c}\text { Asap cair } \\
5 \% \\
\text { Liquid smoke } 5 \%\end{array}$} & $\begin{array}{l}1 \text { jam } \\
1 \text { hour }\end{array}$ & $\begin{array}{l}\text { cokelat muda } \\
\text { light brown }\end{array}$ & $\begin{array}{c}\text { cokelat sangat } \\
\text { pucat } \\
\text { very pale } \\
\text { brown } \\
\end{array}$ & $\begin{array}{c}\text { cokelat sangat } \\
\text { pucat } \\
\text { very pale brown }\end{array}$ \\
\hline & $\begin{array}{l}5 \text { jam } \\
5 \text { hours }\end{array}$ & $\begin{array}{l}\text { cokelat muda } \\
\text { light brown }\end{array}$ & $\begin{array}{c}\text { cokelat sangat } \\
\text { pucat } \\
\text { very pale } \\
\text { brown } \\
\end{array}$ & $\begin{array}{c}\text { cokelat sangat } \\
\text { pucat } \\
\text { very pale brown }\end{array}$ \\
\hline \multirow{2}{*}{$\begin{array}{l}\text { Formalin 5\% } \\
\text { Formalin 5\% }\end{array}$} & $\begin{array}{l}1 \text { jam } \\
1 \text { hour }\end{array}$ & $\begin{array}{c}\text { kuning oranye } \\
\text { pucat } \\
\text { pale orange- } \\
\text { yellow } \\
\end{array}$ & $\begin{array}{c}\text { cokelat sangat } \\
\text { pucat } \\
\text { very pale } \\
\text { brown }\end{array}$ & $\begin{array}{c}\text { cokelat sangat } \\
\text { pucat } \\
\text { very pale brown }\end{array}$ \\
\hline & $\begin{array}{l}5 \text { jam } \\
5 \text { hours }\end{array}$ & $\begin{array}{c}\text { kuning oranye } \\
\text { pucat } \\
\text { pale orange- } \\
\text { yellow }\end{array}$ & $\begin{array}{c}\text { cokelat sangat } \\
\text { pucat } \\
\text { very pale } \\
\text { brown } \\
\end{array}$ & $\begin{array}{c}\text { cokelat sangat } \\
\text { pucat } \\
\text { very pale brown }\end{array}$ \\
\hline \multirow[b]{2}{*}{$\begin{array}{c}\text { Boraks 5\% } \\
\text { Borax 5\% }\end{array}$} & $\begin{array}{l}1 \text { jam } \\
1 \text { hour }\end{array}$ & $\begin{array}{l}\text { cokelat pucat } \\
\text { pale brown }\end{array}$ & $\begin{array}{l}\text { cokelat pucat } \\
\text { pale brown }\end{array}$ & $\begin{array}{l}\text { cokelat pucat } \\
\text { pale brown }\end{array}$ \\
\hline & $\begin{array}{l}5 \text { jam } \\
5 \text { hours }\end{array}$ & $\begin{array}{l}\text { cokelat pucat } \\
\text { pale brown }\end{array}$ & $\begin{array}{l}\text { cokelat sangat } \\
\text { pucat } \\
\text { very pale } \\
\text { brown }\end{array}$ & $\begin{array}{c}\text { cokelat sangat } \\
\text { pucat } \\
\text { very pale brown }\end{array}$ \\
\hline $\begin{array}{l}\text { Kontrol } \\
\text { Control }\end{array}$ & - & $\begin{array}{c}\text { kuning oranye } \\
\text { pucat } \\
\text { pale orange- } \\
\text { yellow } \\
\end{array}$ & $\begin{array}{c}\text { cokelat sangat } \\
\text { pucat } \\
\text { very pale } \\
\text { brown } \\
\end{array}$ & $\begin{array}{c}\text { cokelat sangat } \\
\text { pucat } \\
\text { very pale brown }\end{array}$ \\
\hline
\end{tabular}

menjadi cokelat sangat pucat (very pale brown) sama seperti kontrol setelah penyimpanan.

\section{Derajat proteksi terhadap kerusakan}

Pengamatan terhadap derajat proteksi bahan pengawet terhadap kerusakan baik yang disebabkan serangga maupun jamur harus dilakukan. Hasil pengamatan ini dapat memberikan informasi mengenai tingkat kemampuan bahan pengawet dalam melindungi (proteksi) kayu karet dari mikroorganisme perusak kayu. Nilai derajat proteksi beberapa bahan pengawet disajikan pada Tabel 3.
Seperti terlihat pada Tabel 3 diketahui bahwa bahan pengawet yang paling efektif dalam melindungi kayu karet dari serangan organisme perusak yaitu boraks $5 \%$. Kayu karet yang diawetkan menggunakan boraks $5 \%$ tidak mendapatkan serangan dari organisme perusak kayu. Nilai derajat proteksi kayu karet semua perlakuan perendaman dengan boraks 5\% mencapai 100. Boraks adalah pengawet kayu yang sangat baik untuk melindungi kayu dari pembusukan jamur dan berbagai serangan serangga termasuk semua jenis rayap (Freeman et al., 2014). Boraks telah lama digunakan bersama natrium-pentakhlorofenol (NaPCP) dalam pencegahan jamur pewarna (blue stain) (Barly et al., 2011). 
Bahan pengawet berikutnya yang mempunyai keefektifan cukup baik adalah formalin 5\%. Kayu karet dengan pengawet formalin $5 \%$ yang dibiarkan selama 5 bulan (kurang dari 6 bulan) mempunyai nilai derajat proteksi sebesar 100. Artinya, sampel kayu karet dengan pengawet formalin tidak mendapat gangguan mikroorganisme perusak kayu. Nilai derajat proteksi kayu karet yang direndam dengan formalin $5 \%$ selama 1 jam akan menurun pada bulan ke-6 dimana derajat proteksinya hanya 90. Sedangkan kayu yang direndam formalin 5\% selama 3 jam mempunyai derajat proteksi 100. Kondisi ini terkait dengan retensi bahan pengawet, kayu yang direndam lebih lama mempunyai retensi bahan pengawet yang lebih besar. Jumlah bahan pengawet yang besar di dalam kayu karet akan memberikan perlindungan yang maksimal terhadap serangan organisme perusak.

Kondisi ini berbeda dibandingkan dengan perlakuan menggunakan bahan pengawet organik, ekstrak kunyit dan asap cair. Kemampuan kedua bahan organik ini sebagai bahan pengawet sedikit lebih rendah dibandingkan formalin dan boraks.
Berdasarkan Tabel 3 diketahui bahwa perlakuan kayu karet yang direndam asap cair 5\% selama 1 jam mempunyai nilai derajat proteksi yang lebih baik dibandingkan kayu yang direndam 5 jam, kayu karet dengan pengawet ekstrak kunyit $5 \%$ dan kontrol. Nilai derajat proteksi kayu karet yang direndam asap cair $5 \%$ selama 1 jam sama dengan kayu karet yang direndam formalin 5\% selama 1 jam. Di dalam asap cair terkandung sebanyak 67 senyawa antara lain fenol, asam asetat, pentanedione, asam propanoit dan sebagainya (PSB Corporation, 2003). Dengan kandungan senyawa-senyawa tersebut, asap cair dapat berfungsi sebagai anti-bakteri, anti fungi, antioksidan dan pemberi warna cokelat (Solichin, 2005) sehingga mampu melindungi kayu karet dari serangan mikroorganisme perusak.

\section{KESIMPULAN}

Berdasarkan hasil penelitian yang sudah dilakukan dapat disimpulkan bahwa penggunaan asap cair sebagai bahan pengawet kayu karet lebih baik dibandingkan ekstrak kunyit. Retensi dan

Tabel 3. Nilai derajat proteksi bahan pengawet terhadap kerusakan kayu karet Table 3. The degree of preservatives protection against rubber wood damage

\begin{tabular}{|c|c|c|c|c|}
\hline \multicolumn{2}{|c|}{$\begin{array}{l}\text { Perlakuan } \\
\text { Treatments }\end{array}$} & \multicolumn{3}{|c|}{$\begin{array}{l}\text { Nilai derajat proteksi (bulan) } \\
\text { The degree of protection (months) }\end{array}$} \\
\hline $\begin{array}{c}\text { Jenis bahan pengawet } \\
\text { Preservative type }\end{array}$ & $\begin{array}{l}\text { Lama perendaman } \\
\text { Soaking time }\end{array}$ & 1 & 3 & 6 \\
\hline \multirow{2}{*}{$\begin{array}{l}\text { Ekstrak kunyit 5\% } \\
\text { Turmeric extract } 5 \%\end{array}$} & $\begin{array}{l}1 \text { jam } \\
1 \text { hour }\end{array}$ & 100 & 90 & 80 \\
\hline & $\begin{array}{l}5 \text { jam } \\
\text { 5hours }\end{array}$ & 100 & 90 & 90 \\
\hline \multirow{2}{*}{$\begin{array}{l}\text { Asap cair } 5 \% \\
\text { Liquid smoke } 5 \%\end{array}$} & $\begin{array}{l}1 \text { jam } \\
1 \text { hour }\end{array}$ & 100 & 100 & 90 \\
\hline & $\begin{array}{l}5 \text { jam } \\
5 \text { hours }\end{array}$ & 100 & 90 & 70 \\
\hline \multirow{2}{*}{$\begin{array}{l}\text { Formalin 5\% } \\
\text { Formalin 5\% }\end{array}$} & $\begin{array}{l}1 \text { jam } \\
1 \text { hour }\end{array}$ & 100 & 100 & 90 \\
\hline & $\begin{array}{c}5 \text { jam } \\
5 \text { hours }\end{array}$ & 100 & 100 & 100 \\
\hline \multirow{2}{*}{$\begin{array}{c}\text { Boraks } 5 \% \\
\text { Borax } 5 \%\end{array}$} & $\begin{array}{l}1 \text { jam } \\
1 \text { hour }\end{array}$ & 100 & 100 & 100 \\
\hline & $\begin{array}{c}5 \text { jam } \\
\text { 5vhours }\end{array}$ & 100 & 100 & 100 \\
\hline $\begin{array}{l}\text { Kontrol } \\
\text { Control }\end{array}$ & - & 100 & 90 & 90 \\
\hline
\end{tabular}


derajat proteksi asap cair sebagai bahan pengawet tidak berbeda dibandingkan dengan bahan pengawet kimia boraks dan formalin. Penggunaan asap cair hanya akan mempengaruhi warna kayu karet menjadi cokelat muda setelah perendaman. Warna ini akan berubah selama proses penyimpanan menjadi cokelat sangat pucat. Aplikasi terbaik bahan pengawet asap cair adalah perendaman selama 1 jam.

\section{DAFTAR PUSTAKA}

Agustina, D. S. 2012. Pemanfaatan Kayu Karet di Beberapa Negara Produsen Kayu Karet Alam Dunia. Warta Perkaretan 31 (2): 85 - 94.

Barly dan Subarudi. 2010. Kajian Industri dan Kebijakan Pengawetan Kayu : Sebagai Upaya Mengurangi Tekanan Terhadap Hutan. Jurnal Analisis Kebijakan Kehutanan 7(1): 63 - 80.

Barly, A. Ismanto dan D. Martono. 2011. Dayaguna Campuran Soda Abuboraks Sebagai Antijamur Biru dan Rayap. Jurnal Penelitian Hasil Hutan 29(2) : $179-188$.

Barly dan Krisdianto. 2012. Petunjuk Teknis Pengawetan Kayu Karet. Proyek ITTO PD 253/08 Rev.1 (I).

Boerhendhy, I dan D. S. Agustina. 2006. Potensi Pemanfaatan Kayu Karet untuk Mendukung Peremajaan Perkebunan Karet Rakyat. Jurnal Litbang Pertanian 25(2) : 61-67.

Direktorat Jenderal Perkebunan. 2011. Statistik Perkebunan 2009-2011 : Karet. Sekretariat Direktorat Jenderal Perkebunan, Jakarta.

Freeman, M. H., C. R. McIntyre and D. Jackson. 2014. A Critical and Comprehensive Review of Boron in $\mathrm{W}$ o o d P r e s e r vat i o $\mathrm{n}$. http://nisuscorp.com, diakses pada tanggal 4 Desember 2014.

Hartati, S.Y. 2013. Khasiat Kunyit Sebagai Obat Tradisional dan Manfaat Lainnya. Warta Penelitian dan Pengembangan Tanaman Industri 19(2): 5 - 9.
PSB Corporation. 2003. Test Report Chemical Analysis for "liquid Smoke" Sample. PSB Corporation, Singapore. 1-3

Purwani, E dan Muwakhidah. 2008. Efek Berbagai Pengawet Alami Sebagai Pengganti Formalin Terhadap Sifat Organoleptik dan Masa Simpan Daging dan Ikan. Jurnal Penelitian Sains dan Teknologi 9(1) : 1 - 14.

Putri, N., E. Herawati dan R. Batubara. Pengawetan Kayu Karet (Hevea brasiliensis Muell Arg) Menggunakan Asam Borat $\left(\mathrm{H}_{3} \mathrm{BO}_{3}\right)$ dengan Metode Pengawetan Rendaman Panas Dingin. http:/ / download.portalgaruda.org, diakses pada tanggal 24 November 2014.

Solichin, M. 2005. Optimasi Produksi Asap Cair yang Ramah Lingkungan Sebagai Koagulan Lateks, Penanganan Limbah Bau dan Cair dalam Pengolahan Karet Remah dan Sit Asap. Laporan Akhir Riset Unggulan Kemitraan. Balai Penelitian Sembawa, Sembawa.

Solichin, M., A. Anwar dan N. Tedjaputra. 2007. Penggunaan Asap Cair Deorub dalam Pengolahan RSS. Jurnal Penelitian Karet 25(1) : 83 - 94.

Suheryanto, D. 2010. Pengaruh Konsentrasi Cupri Sulfat Terhadap Keawetan Kayu Karet. Prosiding Seminar Rekayasa Kimia dan Proses 2010. Semarang 4 - 5 Agustus. Jurusan Teknik Kimia, Fakultas Teknik, Universitas Dipenogoro.: E-06. 1-12.

Vachlepi, A dan M. Solichin. 2008. Aplikasi Formula Asap Cair (Deorub K) sebagai Penggumpal Lateks. Warta Perkaretan $27(2): 80-87$.

Woelan, S., N. Siagian, Sayurandi dan S. A. Pasaribu. 2012. Potensi Kayu Karet Hasil Peremajaan di Tingkat Perusahaan Perkebunan. Warta Perkaretan 31 (2) : 75-84. 